\title{
心臟外科を転科した医師を対象とした意識調査
}

\author{
権重 好 清 水剛森住誠末 松義弘
}

第一線で活躍していた心臓外科医が，開業もしくは循環器内科，血管外科に転科するケースを目にする，心 臓外科を離れた医師が，なぜ転科したのかを調査し，現在の心臓外科の環境改善に活用すべくアンケートを 実施した。心臓外科を一度従事し，その後開業もしくは転科した医師（154 名）を対象にアンケートを送付 した．返答数 56 (回答率 $36 \%$ ), 心臓外科に従事していた平均年数 15.4 年, 転科後の平均年数 5.3 年であり, 35 人 $(65 \%)$ が心臟血管外科専門医を取得していた。現在の職種は，一般内科・外科による開業 $(34 \%)$, 循環器内科医 $(20 \%)$, 血管外科医 $(16 \%)$, 一般内科・外科による勤務医 $(14 \%)$, その他 $(16 \%)$ であった. 転科した理由は，1．実家などが開業しており，跡を継ぐため $(16 \%) ， 2$. 経済的な理由 $(15 \%) ， 3$. 人間関 係（12\%）などであった．75\%の医師が「転科後，年収があがった」としている．心臓血管外科専門医を取 得した医師の $63 \%$ が「更新したいが, 手術条件など事実上困難である」としている. 自由記載では, 「自己 犠牲による労㗢が多く, 実働にあった給料が支払われていない」「藏血管外科専門医の更新条件の見直し」 という意見が多かった。它藏血管外科専門医の更新に手術経験が必須であり, 開業や転科後に更新が困難で ある. 専門医として地域医療や後方支援, 後身育成に貢献できる点を考慮すれば, 更新条件の緩和は検討に 値すると考える. また，心臓外科は厳しい労働環境下において実働に見合う評価がされないという意見が少 なくない，心臓外科医の自己犠牲に依存した現況が続けば, 術者育成以前に転科する医師が減らず, 心臓外 科の将来が危惧される. 心臓外科医の取り巻く環境の早急な改善が望まれる. 日心外会誌 41 巻 2 号 : 63-66 (2012)

$$
\text { キーワード：労働環境, 心臓外科医, 転科 }
$$

\section{Survey of Doctors Changed Their Clinical Specialty from Cardiac Surgery}

Shigeyoshi Gon, Tsuyoshi Shimizu, Sei Morizumi and Yoshihiro Suematsu (Cardiovascular Surgery, Tsukuba Memorial Hospital, Tsukuba, Japan)

Some doctors change specialty from cardiac surgery to cardiology or peripheral vascular surgery or practice general medicine before retirement age. We carried out a survey to investigate their working conditions and reasons for changing their specialty. We sent questionnaires by mail to 154 doctors of whom $56(36 \%)$ answered. The most common reason for changing specialty was taking over their family's practice, and the second most common reason was a small income. Actually, the annual income of 41 doctors increased after changing from cardiac surgery (75\%). Many cardiac surgeons have to work with a years lest self-sacrifice and unpaid overtime work. Of the respordents $65 \%$ could not renew their Japanese Board of Cardiovascular Surgery, because of their limited operative numbers. If the current condition continues, the number of cardiac surgeons in Japan will decrease. It is necessary to improve working conditions and the environment so that surgeons can concentrate more on operations. Jpn. J. Cardiovasc. Surg. $41: 63-66$ (2012)

Keywords : working conditions, cardiac surgeon, changing specialty

\section{はじめに}

近年，研修医の外科離れにより中堅外科医個人に要求さ れる負荷が増加している．加えて，心藏外科修練医や第一 線で活躍していた心臓外科医が開業もしくは循環器内科, 血管外科に転科するケースも少なくない。心蔵外科にどう いった不満を抱き，なぜ転科したのかを調査し，現在の心

2011 年 3 月 18 日受付， 2011 年 11 月 15 日採用

筑波記念病院心臟血管外科

干 300-2622 つくば市要 $1187-299$

本論文は第 41 回日本心臓血管外科学会学術総会（2011 年, 千

葉)に打けるシンポジゥムにて発表した。
臓外科の環境改善に活用すべくアンケートを実施した。

\section{対象と方法}

心臓外科を一度従事し, その後開業もしくは転科した医 師（154 名）を対象に 2010 年 3 月に郵送にてアンケート 調査記入を依頼した。質問内容を表 1 に示す。

\section{結果}

返答数 56 (回答率 $36.4 \%$ ), 心藏外科に従事していた平 均年数 15.4 年, 転科後の平均年数 5.3 年であり, 35 人 (65\%) が心臟血管外科専門医を取得, 18 人 $(32 \%)$ が海外 留学経験を有していた。現在の職種は，一般内科・外科に 
表 1 アンケート内容

1. 心臓外科に何年従事しましたか?

2. 転科して何年ですか?

3. 海外留学経験はありますか?

4. 現在の職種・科は何ですか?

5. 転科した主な理由は何ですか？

6. 転科してよかったと思いますか？

7. 転科して年収はあがりましたか?

8. 心臟血管外科専門医を取得していましたか ?

9. 専門医を取得している場合，今後更新していきますか？

10. 専門医はどういった位置づけであるべきと思いますか？

11. 転科した後，他の専門医を取得しましたか？

12. 施設集約化に賛成ですか?

13. 施設集約化することにより, 心臟外科医の労働条件は改 善されると思いますか？

14. 意見を自由に打書きください。
よる開業 (34\%), 循環器内科医 $(20 \%)$, 血管外科医 $(16 \%)$, 一般内科・外科による勤務医 $(14 \%)$, その他 （16\%）であった（図 1)。転科した理由は，1．実家などが 開業しており，跡を継ぐため，2. 経済的な理由，3.人間 関係などであった（図 1).77\%の医師が「転科して良か った」とし， $75 \%$ が「転科後，年収があがった」としてい る (図 2). 心臟血管外科専門医を取得した医師の 22 人 （63\%）が「更新したいが，手術条件など事実上困難であ る」としている (図 3)。蔵血管外科専門医をどのよう に位置づけるかという質問に対しては「specialist 育成の ためもっと厳しくし，専門医の社会的地位向上につなげる べきだ」が $44 \%$, 「専門医は取得しやすくし，さらに上級 の称号（指導医など）を設けるべきだ」が $39 \%$ と意見が 分かれた (図 4). 19 人 (33\%) の医師が転科後, 他の専
現在の職種は何か?

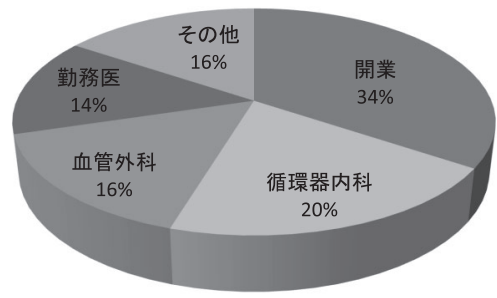

\section{転科した理由は何か？}

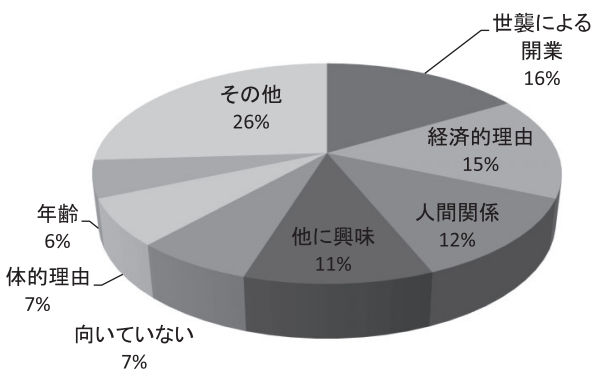

図 1 現在の職種と転科した理由

転科して良かったか？

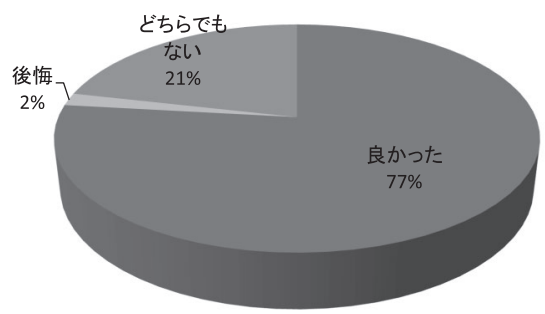

年収は上がったか？

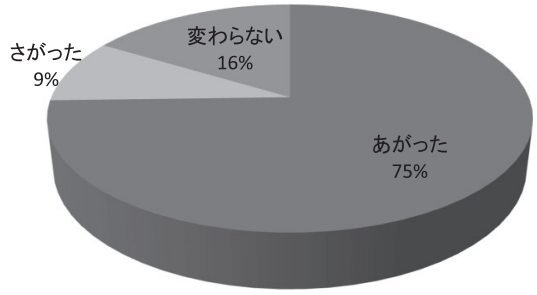

図 2 転科後の状況
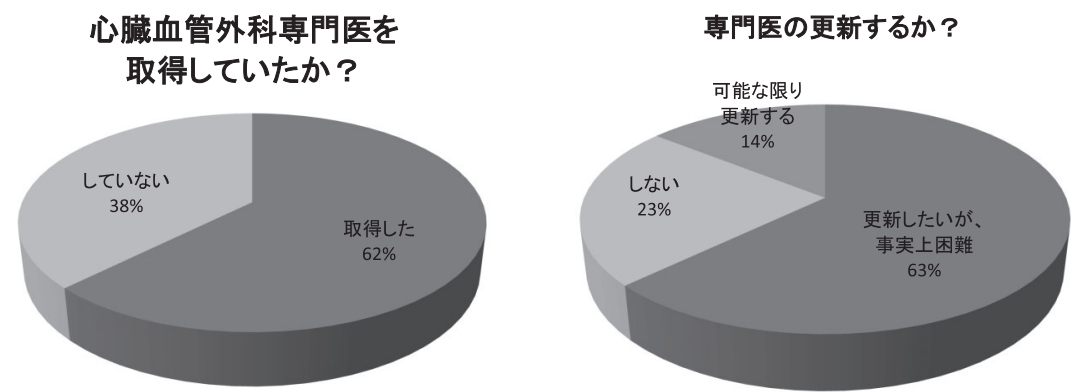

図 3 心臓血管外科専門医更新について 
専門医をどのようにすべきか？

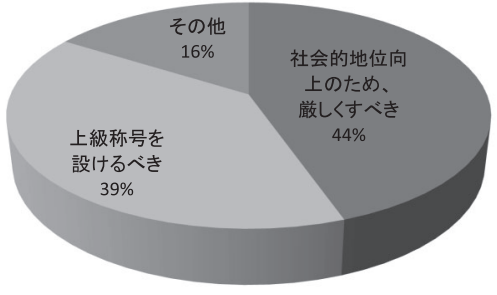

専門医取得困難な医師は

どのようにすべきか?

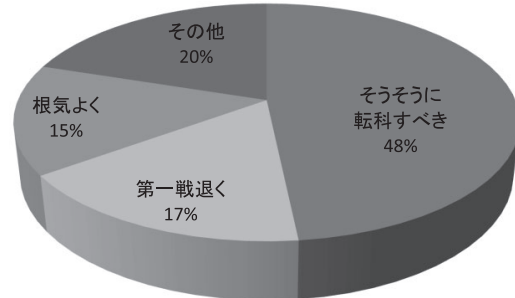

図 4 心臓血管外科専門医について
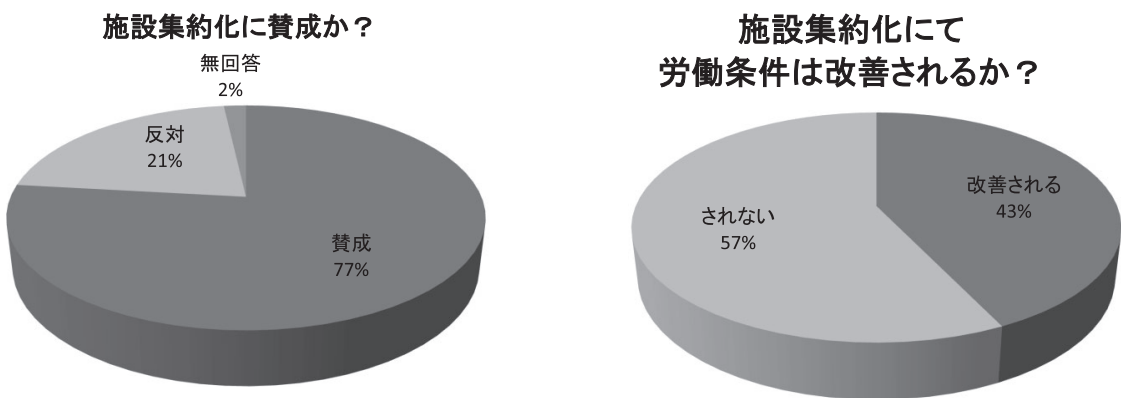

図 5 施設集約化について

門医を取得しており, 循環器専門医（10人）が最も多く, ついで脈管専門医 (5 人), 救急専門医 (2人), 消化器専 門医 ( 2 人), 透析専門医 ( 1 人), 外傷専門医 $(1$ 人), 家 庭医療専門医（1 人）であった。

$77 \%$ の医師が「施設集約化に賛成」としているが，57\% が「集約化のみで労働条件は改善しない」としている（図 5)。自由記載（フリーコメント）の内容は多義にわたった が，特に「自己犠牲による労働が多く，実働にあった給料 が支払われていない」，「心臓血管外科専門医更新に手術経 験が必要であり，実質不可能である．開業していても心臓 血管外科の後方支援可能であり，更新条件の見直しを望 む」，「心藏外科は早期より手術に携わることができず，下 働きばかりで将来が描きにくい」という意見が多かった.

\section{考察}

医師に限らず，最近の若者は生活の質や労働対価を重視 する傾向にあり，研修医の外科離れの理由の一つと考えら れる。研修医の新規外科入局者数減少により，中堅外科医 の負担が増加した。さらには 2004 年の新医師臨床研修制 度以降，大学医局への医師引き上げを招来し，大学関連施 設や地方での医師不足に拍車をかけた。信州大学関連心臟 血管外科施設においては，2002 年から 2008 年の年間手術 症例数が増えたにもかかわらず，入局者数が減少し退職者 数が増えたとしている ${ }^{1)}$. 著者の周囲においても，加齢や 定年退職とは別に，術者として活躍している心臓外科医が
開業もしくは他科に転科するケースを目にする，彼らが転 科に至った経緯を明らかにし，心臓外科の労働条件改善に 活用すべくアンケートを実施した。

転科した理由は世襲による開業が多く，転科後の職種も 開業医が最も多かった。また，多くの医師が心臓外科での 経験が地域医療に役立つとしている。

ついで多かった理由は，経済問題である。事実 $75 \%$ の 医師が「心臓外科を転科後に年収が上がった」とし，自由 記載欄に扔いても「タダ働きが多く，心臟外科の地位向上 を図るべき」との意見が最も多かった，近年の過熱する医 療訴訟のリスクや休日昼夜を問わない緊急対応などの厳し い労働環境でありながら，高い外科的技術が正当に評価さ れていない。田林は外科医の報酬に関し，専門医資格の有 無や個人の技量が反映されておらず，技量による給与の格 差，内科系医師に比して危険を伴う手技に多く携わってい る点を考慮する必要があるとしている ${ }^{2)}$. 医師の技術向上 の incentive として，技術水準を報酬に反映させる制度が 必要である。厚生労働省は「周産期医療と救急医療の確保 と連携に関する懇談会」において，周産期医療を充実させ る取り組みとして，診療報酬上の評価や報酬の一部を医師 の給与に充てるドクターフィーの導入などを検討してい る。日本に打ける診療体制は各診療科が一つの単位として 運営されていることから，手術や検査などに必要な医療技 術の相対的評価を行い，現行の診療報酬体系から各科の診 療報酬点数に換算させるなどの工夫が必要と考える. 
また，多くの心蔵外科医が自己犠牲のもとに術後管理や 緊急対応に迫られ，時間外労働に対する手当が支払われて いない現状がある. 心蔵血管外科専門医認定機構（心血専 認機構）では専門医や修練医に対する処遇改善対策とし て, 夜間・休日の手術に対する時間外手当の支給や過重労 働を抑制する処置などを, 修練施設の認定条件に加える方 向で検討している ${ }^{3)}$. 一日も早い制度改革が期待される が，時間外手当の支給と同時に，今まで外科医の献身的な 努力により支えられてきた周術期管理の負担を軽減する必 要がある. 心血専認機構は医療の安全, 若手の育成扣よび 医療資源の有効活用の観点から施設集約化を図っており, 集約化することにより外科医個人への負担軽減も期待して いる. 本アンケートの結果から $76 \%$ の医師が施設を集約 化すべきだとしているが，57\%の医師が集約化するだけで 労㗢条件は改善しないとしている. Physician assistant (PA) や Nurse practitioner (NP) 制度を導入し, 外科医 が手術に専念できる環境づくりが必要であり, 現況が続け ば術者育成以前に転科する医師が減らず, 心臟外科の将来 が危惧される. 診療報酬点数や福利手当などの労働条件を 改善し, 早急に心臟外科医の社会的地位向上をはかる必要 がある。

心臓血管外科専門医取得に関し「厳しくすべき」が 44\%，「取得しやすくし，上級の称号を設けるべき」が $39 \%$
と意見が分かれたが, 心血専認機構は修練指導者という上 級称号を設け, 平成 22 年度より申請を開始した. 専門医 を取得していた医師の $63 \%$ が更新したいが, 手術条件 など事実上困難である」とし, 更新条件の見直しを求める 意見が多かった。心臓外科医の社会的地位向上を目指し， 他との差別化を図るのであ机ば，専門医の数を制限しなく てはならない，専門医の更新条件を容易にすると専門医の 数が増える可能性があり, 慎重に対応しなければならな い.しかしながら, 専門医として数多く経験を積んたももの や修練指導者においては, 現役ではなくなってもその指導 をとることは可能であるため, 何らかの対応を提示するこ とが必要と思われる。

謝辞 : アンケートに協力していただいた皆様に感謝した い.

\section{文献}

1）高野 環, 福家 愛, 高橋耕平ほか：地方では心臟血管外 科医は減少している一長野県内の心臟血管外科医師と心臟 血管外科症例数の推移一. 日外会誌 $111: 201-205,2010$.

2）田林晄一: 外科医の地位向上に向けて 外科医の立場か ら一外科医の処遇改善をどうするか? 日外会誌 108 （臨 増) : 2-3, 2007.

3）幕内晴朗 : 心臓血管外科専門医制度の現状と問題点. 脈管 学 50 : 257-263, 2010. 